\title{
Genotype Effect on Proximate and Mineral Analysis of Safflower as a Green Leafy Vegetable
}

\author{
Onkgolotse G. Moatshe ${ }^{1}$, Vallantino E. Emongor ${ }^{2} \&$ Patrick K. Mashiqa $^{1}$ \\ ${ }^{1}$ Department of Agricultural Research, Gaborone, Botswana \\ ${ }^{2}$ Crop and Soil Science Department, Botswana University of Agriculture and Natural Resources, Gaborone, \\ Botswana \\ Correspondence: Onkgolotse G. Moatshe, Horticulture Section, Department of Agricultural Research, Private \\ Bag 0033, Gaborone, Botswana. E-mail: ogmoatshe@gov.bw
}

Received: August 20, 2020

doi:10.5539/jas.v12n11p260

\author{
Accepted: September 29, 2020 \\ Online Published: October 15, 2020 \\ URL: https://doi.org/10.5539/jas.v12n11p260
}

\begin{abstract}
Two field trials were carried out at the Botswana University of Agriculture and Natural Resources Content Farm $\left(59^{\circ} 24^{\prime} \mathrm{S}, 95^{\circ} 25^{\prime} \mathrm{E}\right.$ and $993 \mathrm{~m}$ above sea level) in Southern Region of Botswana, to evaluate the effects of genotypes on proximate and mineral composition of safflower leaves. Five safflower genotypes (Kiama composite (local), Sina-PI-537598, Gila-PI-537692, PI-537636 and PI-527710) were evaluated in a randomized complete block design (RCBD) with three replications. During the rosette stage safflower leaves (both petiole and blade) were harvested, dried, and ground for analysis. The results showed that safflower genotypes significantly varied in the leaf proximate content of crude protein (24-28\%), crude fibre (8-14\%), moisture content (86-87\%) and dry matter content (13-14\%) in both winter and summer growing seasons. The genotype 'Sina' had the highest crude fibre content compared to other genotypes. The average leaf mineral content significantly ( $\mathrm{p}<$ 0.05 ) varied from 2-3 $\mathrm{mg} \mathrm{g}^{-1}$ phosphorus, 3-4 mg g $\mathrm{m}^{-1}$ calcium, 5-6 $\mathrm{mg} \mathrm{g}^{-1}$ sodium, $15-17 \mathrm{mg} \mathrm{g}^{-1}$ magnesium and $15-18 \mathrm{mg} \mathrm{g}^{-1}$ potassium. The Na:K and Ca:P ratios ranged between 0.18 and 3.41. All the safflower genotypes evaluated had sufficient nutritional content to be used as a green leafy vegetable for human consumption and food security.
\end{abstract}

Keywords: Carthamus tinctorius L., genotypes, green leafy vegetable (GLV), proximate, mineral nutrition

\section{Introduction}

Safflower is an all year round, drought, heat, cold and saline tolerant oil seed crop. It is a bushy, greatly branched, herbaceous thistle-like annual with long spiny or non-spiny leaves (Singh \& Nimbkar, 2006; Weiss, 2000). It belongs to the family Asteraceae/Compositae with other crops of economic importance such as artichoke (Cynara), lettuce (Lactuca), endive (Cichorium) and salsify (Tragopogon) used as vegetables and sunflower (Helianthus) commonly used as a vegetable oil crop (Archibald, 2011). Safflower plant parts are commercially used for different purposes, for example the seed is used for extraction of high quality cooking oil (Liu et al., 2016; Emongor \& Oagile, 2017), petals are ground for herbal and medicinal purposes (Li \& Mündel, 1996), food colorants, carthamin and carthimidin dyes (J. Cannon \& M. Cannon, 2003), stems are used as cut flowers (Kizil et al., 2008), and leaves are used as vegetables (Sigh et al., 2017). Countries such as India utilise seedlings, thinnings, and bottom leaves of safflower as a leafy vegetable (Suneel-Kumar et al., 2016a, 2016b). Safflower leaves have been recommended for consumption from 30 to 70 days after sowing depending on whether the genotype is spiny or non-spiny (Suneel-Kumar et al., 2015; Suneel-Kumar et al., 2016). As a leafy vegetable, safflower is reported to be palatable and highly nutritious for human consumption with high fibre, minerals, vitamins and antioxidants (Gopalaan, 2004; Sigh et al., 2017). Despite its nutritional status, safflower leaf utilisation as a green leafy vegetable is still minimal and/or unknown in most countries. However, there is an increased interest in research and cultivation of safflower due to its adaptive and nutritive characteristics. Studying nutritional composition of safflower leaves can promote its cultivation and consumption as a leafy vegetable. This can improve household diets and human health nutrition, and contribute to farmer income from early stages of production especially in African countries. The objective of the study was to evaluate the effects of genotypes on proximate and nutritional analysis of safflower leaves during the rosette stage. 


\section{Materials and Methods}

\subsection{Experimental Location}

Two field trials were carried out in the Botswana University of Agriculture and Natural Resources Content Farm $\left(59^{\circ} 24^{\prime} \mathrm{S}, 95^{\circ} 25^{\prime} \mathrm{E}\right.$ and $993 \mathrm{~m}$ above sea level). The soils are shallow, ferruginous tropical soil, mainly consisting of sandy loams (De Wilt \& Nachtengale, 1996; Emongor \& Mabe, 2012). The mean rainfall is $538 \mathrm{~mm}$ per annum. The winter and summer temperatures ranges between $-1{ }^{\circ} \mathrm{C}$ (morning) to $30{ }^{\circ} \mathrm{C}$ (afternoon) and $20^{\circ} \mathrm{C}$ (morning) to $37^{\circ} \mathrm{C}$ (afternoon), respectively (Burgess, 2006).

\subsection{Treatment and Experimental Design}

The trials were laid in a randomized complete block design (RCBD) with three replications, the experimental units were $5 \mathrm{~m} \times 5 \mathrm{~m}$. The treatments comprised of five safflower genotypes (Kiama composite (local/control), Sina-PI-537598, Gila-PI-537692, PI-537636 and PI-527710) grown in winter and summer. These genotypes are the most adaptive and performing genotypes in the semi-arid regions of Botswana.

\subsection{Cultural Practices}

The land was cleared, ploughed followed by disc harrowing to a fine soil tilth. Soil was sampled to determine mineral composition prior to planting. The general fertilizer application for basal dressing was $60 \mathrm{~kg} / \mathrm{ha}$ nitrogen $(\mathrm{N}) ; 30 \mathrm{~kg} / \mathrm{ha}$ phosphorus (P) and $20 \mathrm{~kg} / \mathrm{ha}$ potassium (K) (FAO, 2013). Safflower seed was sown directly at a rate of 2 seeds per hill at a depth of approximately $4.5 \mathrm{~cm}$. This was followed by thinning 15 to 20 days after emergence. All necessary management practices were undertaken to enhance good growth and development. The amount of water applied was according to crop water requirements (ETm) as related to reference evapotranspiration.

\subsection{Data collection: Proximate and Mineral Analysis}

During rosette stage safflower leaves (both petiole and blade) were sampled for proximate and mineral analysis. The rossette stage is an early vegetative growth after emergence with an active leaf growth where leaves accumulate a greater leaf size and number. It is the longest vegetative stage that lasts for 30-40 days after sowing depending on season and genotype (Moatshe \& Emongor, 2019)

\subsubsection{Determination of Moisture Content}

The clean porcelain crucibles were oven dried at $105^{\circ} \mathrm{C}$ for $24 \mathrm{hrs}$, then cooled in a dessicator and weighed $\left(\mathrm{W}_{0}\right)$. Approximately $5.0 \mathrm{~g}$ sample was weighed into a crucible and weighed again as crucible + sample $\left(\mathrm{W}_{1}\right)$. The crucible with sample was oven dried at $105^{\circ} \mathrm{C}$ for $48 \mathrm{hrs}$ and cooled in a desiccator before they are reweighed $\left(\mathrm{W}_{2}\right)$. The percentage moisture content was calculated as:\% moisture content $=\left(\mathrm{W}_{1}-\mathrm{W}_{2}\right) /\left(\mathrm{W}_{1}-\mathrm{W}_{2}\right) \times 100$

\subsubsection{Determination of Dry Matter Content}

Leaf dry matter (DM) was determined according to AOAC (1996). The dry matter (DM) was determined by weighing approximately $1 \mathrm{~g}$ of ground sample into pre-weighed crucibles and placed in an oven set at $66^{\circ} \mathrm{C}$ for 72 hours. Dry matter was determined as the difference between initial sample weight and moisture weight and expressed as a percentage.

\subsubsection{Crude Fibre Determination}

This was determined according to (AOAC, 1996). The dried sample was ground and approximately $1.0 \mathrm{~g}\left(\mathrm{~W}_{0}\right)$ was weighed into a fritted glass crucibles and hydrolysed with boiling $0.128 \mathrm{M}$ sulphuric acid, followed by boiling in $0.223 \mathrm{M}$ potassium hydroxide solution in hot extractor. The residue was washed with preheated distilled water before being transferred to a cold extractor and washed with acetone. The residue and crucibles were oven dried at $105^{\circ} \mathrm{C}$ overnight and weighed $\left(\mathrm{W}_{1}\right)$ before being ignited into a muffle furnace at $450{ }^{\circ} \mathrm{C}$ for $8 \mathrm{hrs}$. The residual ash was first cooled in an oven at $105^{\circ} \mathrm{C}$ overnight, then cooled to room temperature in a dessicator and weighed $\left(\mathrm{W}_{2}\right)$. The percentage of crude fibre was calculated as:\% Crude Fibre $=\left(\left(\mathrm{W}_{1}-\mathrm{W}_{2}\right) / \mathrm{W}_{\mathrm{o}}\right) \times 100$.

\subsubsection{Crude Protein Determination}

The ground dry sample was digested in a BD block at $330{ }^{\circ} \mathrm{C}$ for 7 hours. After digestion, nitrogen (N) was determined through distillation and titration using the micro-kjeldahl method (AOAC, 1996). The crude protein content was calculated by multiplying percentage $\mathrm{N}$ content by a factor of 6.25 (AOAC, 1996).

\subsubsection{Mineral Analysis Procedure}

The leaf samples were oven-dried at $66^{\circ} \mathrm{C}$ to constant weight. The dried samples were ground using a sieve of size two and $1.25 \mathrm{~g}$ composite sample digested in $20 \mathrm{ml}$ sulphuric acid (98\%) and $4 \mathrm{ml}$ hydrogen peroxide (30\%) in a BD block at $330{ }^{\circ} \mathrm{C}$ for 7 hours. Phosphorus (P) was determined calorimetrically using sodium phenol and 
ammonium molybdate plus ascorbic acid method (AOAC, 1996). The absorbance of phosphorus, calcium (Ca), magnesium (mg) and potassium (K) was read in an Optimal Emission Spectrophotometer using Inductively Coupled Plasma of model Optima 7300 DV. Data was expressed as total mineral content in $\mathrm{mg} \mathrm{g}^{-1}$ on dry weight basis.

\subsection{Statistical Analysis}

Analysis of variance was performed on the data collected using general linear model (PROC GLM) procedure of Statistical Analysis System (SAS 2009, Carey, NC) program package. Multiple comparisons among means was done using Protected Least Significant Difference (LSD) at $P=0.05$.

\section{Results}

\subsection{Safflower Leaf Proximate Analysis}

Safflower genotypes significantly $(P<0.05)$ varied in leaf moisture and dry matter contents in winter and summer (Table 1). Leaf moisture content $($ LMC) significantly $(P<0.05)$ ranged between $86-89 \%$ and $85-87 \%$ in winter and summer, respectively (Table 1). While the leaf dry matter (LDM) ranged between $11-14 \%$ and $13-15 \%$ in winter and summer, respectively (Table 1). In winter and summer, the genotypes Kiama and PI-527710 had significantly $(P<0.05)$ the highest and lowest LMC and LDM, respectively (Table 1). Winter grown safflower had significantly $(P<0.05)$ higher and lower LMC and LDM than summer (Table 1).

Table 1. Effect of genotype on proximate analysis of safflower leaves

\begin{tabular}{|c|c|c|c|c|c|c|c|c|}
\hline \multirow{2}{*}{ Genotypes } & \multicolumn{2}{|c|}{ Crude fibre (\%) } & \multicolumn{2}{|c|}{ Crude protein (\%) } & \multicolumn{2}{|c|}{ Moisture content (\%) } & \multicolumn{2}{|c|}{ Dry matter content $(\%)$} \\
\hline & Winter & Summer & Winter & Summer & Winter & Summer & Winter & Summer \\
\hline Sina & $17.51 \mathrm{a}$ & $8.98 \mathrm{ba}$ & $21.12 \mathrm{c}$ & $21.38 \mathrm{~b}$ & $87.21 \mathrm{~b}$ & $86.59 \mathrm{~b}$ & $12.79 \mathrm{c}$ & $13.41 \mathrm{bc}$ \\
\hline Kiama & $9.39 \mathrm{c}$ & $9.14 \mathrm{ba}$ & $37.07 \mathrm{a}$ & $22.90 \mathrm{~b}$ & $89.40 \mathrm{a}$ & $84.58 \mathrm{c}$ & $10.60 \mathrm{~d}$ & $15.42 \mathrm{a}$ \\
\hline Gila & $15.12 \mathrm{~b}$ & $6.95 \mathrm{c}$ & $24.42 b$ & $28.84 \mathrm{a}$ & $85.81 \mathrm{c}$ & $86.85 b$ & $14.19 \mathrm{a}$ & $13.15 \mathrm{c}$ \\
\hline PI-527710 & $10.15 \mathrm{c}$ & $8.36 \mathrm{~b}$ & $34.85 a$ & $29.57 \mathrm{a}$ & $86.81 \mathrm{cb}$ & $88.80 \mathrm{a}$ & $13.19 \mathrm{bc}$ & $11.20 \mathrm{~d}$ \\
\hline PI-537636 & $15.72 \mathrm{ba}$ & $9.97 \mathrm{a}$ & $21.19 \mathrm{c}$ & $18.68 \mathrm{~b}$ & $86.51 \mathrm{cb}$ & $86.06 \mathrm{~b}$ & $13.49 \mathrm{~b}$ & $13.94 b$ \\
\hline Mean & 13.58 & 8.68 & 27.73 & 24.27 & 87.15 & 86.58 & 12.85 & 13.42 \\
\hline Significance & $* * * *$ & $* *$ & $* * * *$ & $* * * *$ & $* * *$ & $* *$ & $* * * *$ & $* * *$ \\
\hline LSD & 2.21 & 1.38 & 0.49 & 0.65 & 1.24 & 0.81 & 0.70 & 0.74 \\
\hline
\end{tabular}

Note. ${ }^{* *}, * * *, * * * *$ Significance at $P=0.01,0.001,0.0001$, respectively. Means separated using the Least Significant Difference (LSD) at $P=0.05$; Means with the same letter(s) are not significantly different.

The crude fibre content (CFC) of safflower genotypes on study ranges between 7 to $16 \%$ irrespective of season (Table 1). For the genotypes studied, average crude fibre content of safflower leaves was higher in winter than summer by $36 \%$ difference, genotype 'Sina' produced more CFC compared to other genotypes (Table 1). The crude protein content $(\mathrm{CPC})$ of safflower leaves significantly $(P<0.05)$ ranged between 21 to $37 \%$ and 19 to $30 \%$ in winter and summer grown genotypes, respectively (Table1). Comparing winter genotypes, 'Sina' and 'Kiama' had the lowest and highest protein content of 21 and 37\%, respectively. However, genotypes 'Sina' and 'PI-537636' or 'Kiama' and 'PI-527710' did not significantly differ (Table 1). Whereas in summer genotypes 'PI-537636' and 'PI-527710' had the lowest and highest protein of 19 and 30\%, respectively (Table 1). Genotype 'PI-537636' had no significant difference with all other genotypes studied with exception of 'PI-527710' and 'Gila' (Table 1).

\subsection{Safflower Leaf Mineral Analysis}

Safflower genotypes had a significant $(P<0.05)$ effect on leaf mineral content $(\mathrm{P}, \mathrm{K}, \mathrm{Mg}, \mathrm{Ca}, \mathrm{Na})$ of safflower grown in both seasons (Table 2). Phosphorus content for winter harvested leaves significantly $(P<0.05)$ ranged between 1-3 $\mathrm{mg} \mathrm{g}^{-1}$, during this season all genotypes were not significantly $(P>0.05)$ different except for 'Kiama' which had the lowest $P$ value of $1 \mathrm{mg} \mathrm{g}^{-1}$ (Table 2). Summer grown genotypes significantly $(P<0.05)$ differed in phosphorus content at a range between $1-2 \mathrm{mg} \mathrm{g}^{-1}$, all genotypes had no significant difference with exception of 'PI-527710' (Table 2). Genotype 'PI-527710' had the highest P value in both seasons (Table 2).

Safflower leaf potassium levels significantly $(P<0.05)$ ranged between $13-20 \mathrm{mg} \mathrm{g}^{-1}$ and $12-21 \mathrm{mg} \mathrm{g}^{-1}$ across genotypes in winter and summer, respectively (Table 2). Genotypes 'PI-537636' and 'PI-527710' resulted with the highest potassium content in winter and summer, respectively (Table 2). For both seasons, all genotypes did not 
significantly $(P>0.05)$ differ in potassium content except for 'Kiama' or 'PI-527710' in winter or summer, respectively (Table 2).

The average leaf magnesium $(\mathrm{mg})$ significantly $(P<0.05)$ ranged between $15-17 \mathrm{mg} \mathrm{g}^{-1}$ in both seasons (Table 2). There was $22 \%, 27 \%, 32 \%, 12 \%$ and $24 \%$ seasonal difference on magnesium rate of safflower genotypes 'Sina', 'Kiama', 'Gila', 'PI-527710' and 'PI-537636', respectively (Table 2). The highest magnesium level was 20 and 22 $\mathrm{mg} \mathrm{g}^{-1}$ from genotypes 'Kiama' and 'Gila' in winter and summer, respectively.

Table 2. Effect of genotype on mineral composition of safflower leaves

\begin{tabular}{|c|c|c|c|c|c|c|c|c|c|c|}
\hline \multirow{2}{*}{ Genotype } & \multicolumn{2}{|c|}{ Phosphorus (mg/g) } & \multicolumn{2}{|c|}{ Potassium (mg/g) } & \multicolumn{2}{|c|}{ Magnesium (mg/g) } & \multicolumn{2}{|c|}{ Calcium (mg/g) } & \multicolumn{2}{|c|}{ Sodium $(\mathrm{mg} / \mathrm{g})$} \\
\hline & Winter & Summer & Winter & Summer & Winter & Summer & Winter & Summer & Winter & Summer \\
\hline Sina & $2.60 \mathrm{a}$ & $1.68 \mathrm{cb}$ & $19.75 \mathrm{ba}$ & $13.87 \mathrm{~b}$ & $12.78 \mathrm{c}$ & $16.27 \mathrm{~b}$ & $2.60 \mathrm{a}$ & $3.28 \mathrm{c}$ & $5.94 \mathrm{ba}$ & $4.53 b$ \\
\hline Kiama & $1.30 \mathrm{~b}$ & $1.35 \mathrm{~d}$ & $12.88 \mathrm{c}$ & $11.48 \mathrm{~b}$ & $19.69 \mathrm{a}$ & $14.29 \mathrm{c}$ & $1.30 \mathrm{~b}$ & $3.46 \mathrm{c}$ & $3.67 \mathrm{c}$ & $5.65 \mathrm{a}$ \\
\hline Gila & $2.79 \mathrm{a}$ & $1.49 \mathrm{~cd}$ & $17.51 \mathrm{~b}$ & $13.48 \mathrm{~b}$ & $14.77 \mathrm{~b}$ & $21.55 \mathrm{a}$ & $2.79 \mathrm{a}$ & $5.08 \mathrm{a}$ & $5.85 \mathrm{~b}$ & $5.34 \mathrm{ba}$ \\
\hline Pi-527710 & $2.93 \mathrm{a}$ & $2.26 \mathrm{a}$ & $18.91 \mathrm{ba}$ & $21.30 \mathrm{a}$ & $15.42 \mathrm{~b}$ & $17.46 \mathrm{~b}$ & $2.93 \mathrm{a}$ & $4.62 b$ & $6.08 \mathrm{ba}$ & $3.45 \mathrm{c}$ \\
\hline Pi-537636 & $2.87 \mathrm{a}$ & $1.95 \mathrm{~b}$ & $19.96 \mathrm{a}$ & $15.44 \mathrm{~b}$ & $12.48 \mathrm{c}$ & $16.44 \mathrm{~b}$ & $2.87 \mathrm{a}$ & $3.67 \mathrm{~b}$ & $7.50 \mathrm{a}$ & $4.47 \mathrm{~b}$ \\
\hline Mean & 2.50 & 1.75 & 17.80 & 15.11 & 15.03 & 17.20 & 2.50 & 4.02 & 5.81 & 4.69 \\
\hline Significance & $* *$ & $* * *$ & $* * *$ & * & $* * *$ & $* * *$ & $* *$ & $* * * *$ & $* *$ & $* *$ \\
\hline LSD & 0.89 & 0.49 & 2.32 & 4.89 & 1.92 & 1.87 & 0.89 & 0.46 & 1.59 & 0.91 \\
\hline
\end{tabular}

Note. ${ }^{*}, * *, * * *, * * * *$ Significance at $P=0.05,0.01,0.001,0.0001$, respectively. Means separated using the Least Significant Difference (LSD) at $P=0.05$; Means with the same letter(s) are not significantly different.

In winter, leaf calcium content significantly $(P<0.05)$ ranged between $1-3 \mathrm{mg} \mathrm{g}^{-1}$ (Table 2). Genotype 'PI-527710' produced the highest calcium content of $3 \mathrm{mg} \mathrm{g}^{-1}$, however it did not significantly $(P>0.05)$ differ from all other genotypes except 'Kiama' which had the lowest calcium value. Safflower calcium level of summer harvested leaves significantly $(P<0.05)$ ranged between $3-5 \mathrm{mg} \mathrm{g}^{-1}$ among genotypes (Table 2$)$. Genotype 'Sina' had the lowest calcium content compared to other genotypes, however it did not significantly $(P>0.05)$ differ from 'Kiama' (Table 2). Similarly, calcium content of genotypes 'PI-527710' and 'PI-537636' had no significant difference (Table 2). The highest calcium content of $5 \mathrm{mg} \mathrm{g}^{-1}$ was produced by genotype 'Gila' in summer (Table 2).

The sodium content significantly $(P<0.05)$ ranged between $4-8$ and $4-6 \mathrm{mg} \mathrm{g}^{-1}$ in winter and summer conditions, respectively (Table 2). During winter, the lowest and highest leaf sodium content was from genotypes 'Kiama' and 'PI-537636', however 'PI-537636' was not significantly $(P>0.05)$ different to all other genotypes except 'Kiama' (Table 2). In summer, genotypes 'PI-527710' and 'Kiama' had significantly $(P<0.05)$ lowest and highest sodium content (Table 2). Similar to winter, all genotypes in summer were not significantly different in leaf sodium content except for 'PI-527710' (Table 2). In general, winter harvested leaves were $19 \%$ higher in average leaf sodium content compared to summer across genotypes (Table 2).

The leaf Na:K ratio significantly $(P<0.05)$ ranged below 1 in both seasons, however winter genotypes had no significant difference (Figure 1). Minimum and maximum Na:K ratio of summer was from genotypes 'PI-527710' and 'Kiama', all other genotypes (PI-537636, Sina, Gila) were not significantly $(P<0.05)$ different (Figure 1). Ca:P levels significantly $(P<0.05)$ ranged from 1-3 irrespective of genotypes in winter and summer (Figure 1). Genotypes did not significantly $(P>0.05)$ differ in leaf Ca:P ratio except for 'Kiama' which had the highest Ca:P ratio (Figure 1). In summer, the lowest ratio was from genotype 'PI-537636', however it had no significant difference from that of genotypes 'Sina' or 'PI-527710'. Genotype 'Gila' recorded the highest leaf Ca:P ratio of 3 (Figure 1). 


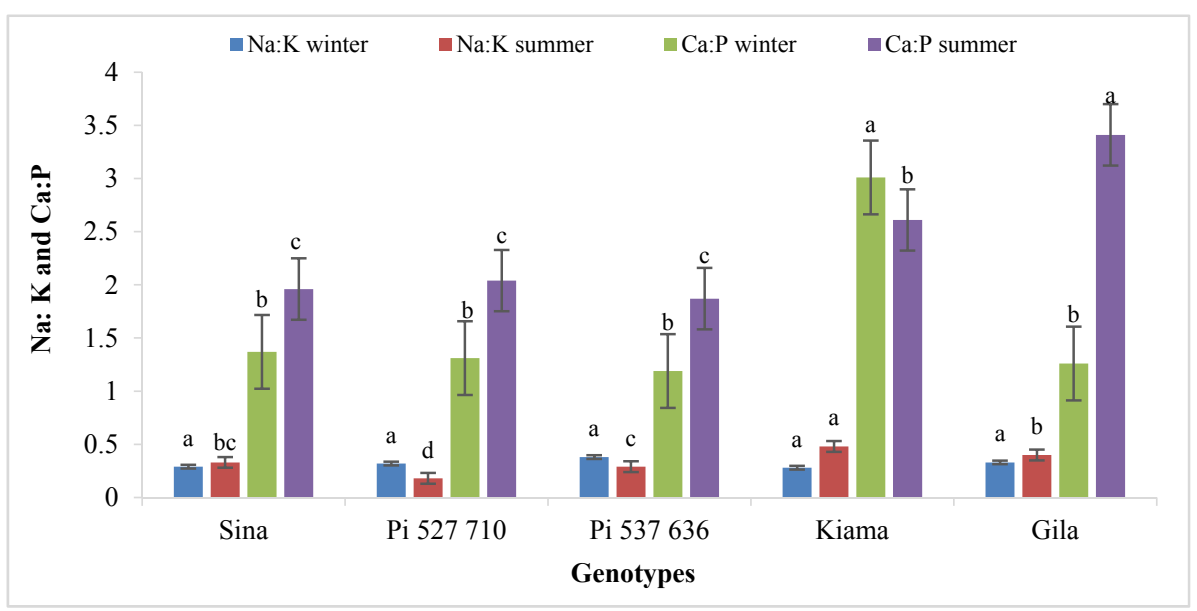

Figure 1. Effect of genotype on leaf mineral ratio of safflower planted in winter and summer; bars with the same letter are not significantly different; mean separation by LSD at $\mathrm{P}=0.05$

\section{Discussion}

The genotypic difference in proximate and mineral nutrition of safflower across seasons indicate that nutritional benefit on consumption of safflower leaves varies depending on the genotype. The variation is attributed to genetic differences in the genotypes under investigation in response to environmental conditions during winter and summer. Safflower genotypes differ in growth habits, morphology and physiological performance, this differences affect the source-sink strength hence causing differences in mineral nutrition and its partitioning. However, despite the differences most genotypes had shown to be good source of mineral nutrition indicating a sufficient nutritional distribution among safflower leaves. This was consistent with the findings of Suneel-Kumar et al. (2016) who reported variation on leaf nutrition (calcium, iron, crude fibre, ash, protein and moisture content) as affected by genotype and growth stage. Different authors studying mineral composition of leafy vegetables reported significant genotypic difference, which is influenced by genetic factors, crop growth habits, cultural and environmental conditions (Chope \& Terry, 2009; Rouphael et al., 2012; Kunyanga et al., 2013).

From the current study crude fibre content for genotypes 'Sina', 'Kiama', PI-527710', 'Gila' and 'PI-537636' ranged between $7-18 \%$. This implies that every $100 \mathrm{~g}$ of safflower leaves harvested from genotype 'Sina' can provide $18 \%$ of crude fibre, this is within the recommended daily allowance as reported by Adinortey et al. (2012). Thus safflower leaf genotypes has an adequate dietary fibre essential for human health. Similar findings were reported by Suneel-Kumar et al. (2016a) who reported safflower leaf genotypes tobe rich in crude fibre content at any growth with $9 \%$ crude fibre content produced from safflower genotypes ('Annigeri-1', 'Manjira', TSF-1 and NARI-6) harvested at 30-70 days after sowing.Oduro et al. (2008) and Kunyanga et al. (2013) also found the same range, studying leaf crude fibre content of sweet potato (7.2\%), amaranthus (8.64\%) and pumpkin (12.04\%). High crude fibre means high soluble fibre content, essential for lowering plasma, serum cholesterol levels and gastro intestinal function hence stimulating tracolonic pressure for diverticular illness such as colon cancer (Khalil et al., 2012; Dawszynski et al., 2007) and constipation (Ogungbenle \& Omosola, 2015).

Safflower leaves has an average crude protein content of $24-27 \%$ with genotype 'Kiama' recording the highest protein level compared to other genotypes in winter or summer. This means $100 \mathrm{~g}$ of safflower leaves at dry weight basis is twice the recommended intake for children and 43-79\% that of adults. Pearson (1976) confirmed that plant foods should contain more than $12 \%$ of its caloric value as a good source of protein. Food and nutrition board for Institute of medicine (2002) reported that the daily required intake of crude protein ranges between 9-13 $\mathrm{g}$ and 34-56 $\mathrm{g}$ for children and adults, respectively. This indicates that any safflower leaf genotype studied harvested in either winter or summer are nutritionally sufficient as a protein source for consumption to improve protein deficiencies. In both seasons, any safflower genotype studied had an optimal leaf moisture content of a range between $85-89 \%$ indicating its freshness and adequacy of water soluble vitamins (Adinortey et al., 2012).

Despite the significant $(\mathrm{P}<0.05)$ variation among genotypes towards mineral composition, potassium and magnesium were higher compared to other elements. The lowest mineral content among the genotypes was phosphorus at an average of 2-3 $\mathrm{mg} \mathrm{g}^{-1}$ across seasons. Potassium as the abundant mineral in safflower leaves significantly varied among genotypes with the lowest and highest value ranging between $11-21 \mathrm{mg} \mathrm{g}^{-1}$ in winter and summer. The safflower leaves are a good source of potassium as $100 \mathrm{~g}$ leaves of genotypes studied harvested 
in any season can contribute a range between $60-105 \% \mathrm{~K}$ daily intake as per daily recommended allowance for adults (The National Research Council, 1989). Potassium is beneficial for hypertension patients (Arinathan et al., 2003) and has a synergistic relationship with other essential minerals as it was reported to increase the utilisation of iron in the body (Adeyeye, 2002).

Safflower genotypes can provide a significant amount of leaf dietary calcium. Suneel-Kumar et al. (2016) found the same results and reported 2-3 $\mathrm{mg} \mathrm{g}^{-1} \mathrm{Ca}$ in safflower leaves. The values are consistent to those of other leafy vegetables studied including okra (1.1-3.1 $\left.\mathrm{mg} \mathrm{g}^{-1}\right)$ and Amaranthus $\left(2.64 \mathrm{mg} \mathrm{g}^{-1}\right)$ (Gemede et al., 2015; Kunyanga et al., 2013). The National Research Council (1989) reported the recommended daily allowance of $8 \mathrm{mg}$ per $100 \mathrm{~g}$ per day of calcium for both adults and children. In the current study, safflower leaves can provide $41-64 \%$ of required daily intake in every $100 \mathrm{~g}$ depending on the genotype. Calcium concentrations are adequate for blood coagulation and integrity of intracellular cement substances (J. C. Okaka \& A. N. O. Okaka, 2011).

Safflower leaves $(100 \mathrm{~g})$ provides $18-42 \%$ or $26-59 \%$ of sodium for adults and children, respectively depending on the genotype and season of growth. This is a sufficient amount to be incorporated in daily diets for human consumption to meet the required intake as reported by Food and Nutrition Board of National Academy of Sciences (2002).

There is a recommended mineral ratios essential for intake restrictions on individuals with nutrition associated diseases. People suffering from acute or chronic renal failure under haemodialysis require controlled potassium intake levels (Copetti et al., 2010). The study at present indicates that safflower leaves contains $\mathrm{Na}: \mathrm{K}$ ratio of 0.2 to 0.5 among genotypes, this value is within the recommended $\mathrm{Na}: \mathrm{K}$ ratio in human diets which is reported to be less than 1 (Copetti et al., 2010). Based on this ratios, the consumption of safflower leaves may be adequate for hypertension patients to lower the blood cholesterol (Adinortey et al., 2012; Sodamade et al., 2013) and normal protein retention during growth stages (Nieman et al., 1992). Vegetables are considered adequate for consumption when $\mathrm{Ca}: \mathrm{P}$ ratio is above 1 , while the $\mathrm{Ca}: \mathrm{P}$ ratio below 0.5 means an inadequate mineral source. Safflower genotypes studied contain Ca:P ratio of 1-3 depending on season. This indicates that safflower leaves are essential for consumption by children and lactating women essential for maintenance of bone, teeth and muscles (Turan et al., 2003; Sodamade et al., 2013).

\section{Conclusion}

Safflower as a leafy vegetable is an important food source, adequate for human consumption due to its nutritional value which meets the nutritional recommended daily allowances for different age and/or health groups. All genotypes of safflower studied significantly varied and influenced the leaf proximate and mineral nutrition resulting with a high crude fibre and protein content of $18 \%$ and $37 \%$ from genotypes 'Sina' and 'Kiama' respectively. In terms of mineral nutrition, genotype 'PI-527710' was the most nutritious with the highest $\mathrm{P}, \mathrm{K}, \mathrm{Ca}$, $\mathrm{Na}$ depending on season as compared to other genotypes. This indicates that safflower genotypes under study can be consumed as a green leafy vegetable in any season or used for value addition to improve quality and nutritional value of other food formulation for infants, adults and nutrition deficient groups. The study suggests that consumption of safflower leaves can enhance food security, increase farmer revenue and be recommended for use in supplementary diets such as hypo-cholesterol diets, consumption by groups with coronary disease problems and protein malnutrition in infants.

\section{References}

Adeyeye, E. I. (2002). Determination of the chemical composition of the nutritionally valuable parts of male and female common West African fresh water crab Sudananautes africanus africanus. International Journal of Food Sciences and Nutrition, 53, 189-196. https://doi.org/10.1080/09637480220132805

Adinortey, M. B., Sarfo, J. K., Quayson, E. T., Weremfo, A., Adinortey, C. A., Ekloh, W., \& Ocran, J. (2012). Phytochemical screening, proximate and mineral composition of Launaea taraxacifolia leaves. Research Journal of Medicinal Plants, 6, 171-179. https://doi.org/10.3923/rjmp.2012.171.179

AOAC (Association of Official Analytical Chemists). (1996). Association of Official Analytical Chemists Official Methods of Analysis (17th ed.). Arlington, Virginia, USA.

Archibald, C. J. (2011). Linkage mapping, phenotypic characterization and introgression analysis of crosses with safflower (Carthumus tinctorious) (Msc Plant Biology. University of Alberta, Alberta).

Arinathan, V., Mohan, V. R., \& Britto, A. J. (2003). Chemical composition of certain tribal pulses in South India. International Journal of Food Sciences and Nutrition, 54, 209-217. https://doi.org/10.1080/096374801200 92026 
Burgess, J. (2006). Country Pasture/Forage Resource Profiles: Botswana (p. 45). Food Agricultural Organization.

Cannon, J., \& Cannon, M. (2003). Dye plants and dyeing (p. 128). Royal Botanic Gardens, Kew.

Chope, G. A., \& Terry, L. A. (2009). Use of calorical variate analysis to differentiate onion cultivars by mineral content as measured by 1 CP-AES. Food Chemistry, 115(3), 1108-1113. https://doi.org/10.1016/j.foodchem. 2008.12.090

Copetti, C., de Oliveira, V. R., \& Kirinu, P. (2010). Evaluation of potassium in vegetables submitted to different cooking methods and their possible use in renal diet. Review Nutrition, 23(5), 831-838. https://doi.org/ $10.1590 / \mathrm{s} 1415-52732010000500013$

Dawzynski, C., Schubert, R., \& Jahreis, G. (2007). Amino acids, fatty acids and dietary fibre in edible seaweed products. Food Chemistry, 103, 891-899. https://doi.org/10.1016/j.foodchem.2006.09.041

De-Wilt, P. V., \& Nightengaele, F. O. (1996). Explanatory notes on soil map of Republic of Botswana. Soil mapping and advisory services (p. 48). Botswana.

Emongor, V. E., \& Mabe, O. (2012). Effects of phosphorus on growth, yield and yield components of chilli pepper (Capsicum annum L.). Acta Horticulturae, 936, 327-334. https://doi.org/10.17660/ActaHortic.2012.936.42

FAO (Food Agriculture Organisation). (2013). Crop water information: Safflower (p. 8). Water Development and Management Unit.

FNB (Food National Board). (2002). Dietary reference intakes for energy, carbohdrates, fiber, fat, fatty acids, cholesterol, protein and amino acids. Food and Nutrition Board, Institute of Medicine of the National Academies, The National Academies Press, Washington, D.C. Retrieved from https://www.nap.edu/open bookphp? Isbn=0309085373

Gopalan, C., Rama, S. B. V., \& Balasubramanian, S. C. (2004). Nutritive value of Indian foods. Nutritional Institute of Nutrition, ICMR, Hyderabad.

Gemede, H. F., Haki, G. D., Beyene, F., Woldegiorgis, A. Z., \& Rakshit, S. K. (2015). Proximate, mineral and antinutrient compositions of indigenous Okra (Abelmoschus esculentus) pod accessions: Implications for mineral bioavailability. Food Science and Nutrition, 4(2), 223-233. https://doi.org/10.1002/fsn3.282

Khalil, E., Esoh, R., Rababah, T., Almajwal, A. M., \& Muhammad, H. A. (2012). Minerals and proximate composition and their correlations of medicinal plants from Jordan. Journal of Medicinal Plants Research, 6(47), 5757-5762. https://doi.org/10.5897/JMPR10.022

Kizil, S., Cakmak, O., Kirci, S., \& Inan, M. (2008). A comprehensive study on safflower (Carthumus tinctorious L.) in semi arid conditions. Biotechnology and Biotechnology Equation, 22(4), 947-953. https://doi.org/ $10.1080 / 13102818.10817585$

Kunyanga, C. N., Imungi, J. K., \& Vadiuel, V. (2013). Nutritional evaluation of indigenous foods with potential food based solution to alleviate hunger and malnutrition in Kenya. Journal of Applied Biosciences, 67, 5277-5288. https://doi.org/10.4314/jab.v67i0.95049

Li, D., \& Mundel, H. H. (1996). Safflower (Carthamus tinctorius L.): Promoting the Conservation and Use of Underutilized and Neglected Crops (Vol. 7, p. 83). Institute of Plant Genetics and Crop Plant Research, Gatersleben/International Plant Genetic Resources Institute, Rome.

Liu, L., Guan, L., \& Yang, Y. (2016). A review of fatty acid and genetic characterization of safflower (Carthamus tinctorious L.) seed oil. World Journal of Traditional Chinese Medicine, 2(2), 48-52. https://doi.org/ 10.4172/2161-0401-1000160

Singh, V., \& Nimbkar, N. (2006). Safflower (Carthumus tinctorius. L). Genetic Resources, Chromosome Engineering and Crop Improvement, 6, 167-194. https://doi.org/10.1201/9781420005363.ch6

Suneel-Kumar, E., Aparna, K., Padmavathi, P., Durga Rani, Ch. V., Supraia, T., \& Supta, S. (2016a). Nutrient composition of selected cultivars of safflower (Carthumus tinctorious L.) leaves during different crop growth stages to water stress. Journal of Oilseeds Research, 33(4), 216-220. Retrieved from https://www.researchgate.net/publication/325476908

Suneel-Kumar, E., Aparna, K., Padmavathi, P., Durga Rani, Ch. V., Supraia, T., \& Supta, S. (2016b). Changes in antioxidant content in selected cultivars of safflower (Carthumus tinctorious L.) leaves during different stages of maturity. Journal of Oilseeds Research, 33(1), 51-55. Retrieved from https://www.researchgate. net/publication/325477415 
Suneel Kumar, E., Aparna, K., Padmavathi, P., Durga Rani, Ch. V., Supraia, T., \& Supta, S. (2015). Sensory characteristics of different stages of safflower (Carthumus tinctorious L.) leaves and leaf powder incorporated products. Journal of Oilseeds Research, 33(1), 56-62. Retrieved from https://www.research gate.net/publication/318959277

NRC (National Research Council). (1989). Recommended Dietary Allowances. National Academy Press, Washington D.C.

Nieman, D. C., Butterworth, D. E., \& Nieman, C. N. (1992). Nutrition (pp. 237-312). WMC Brown Publishers, Dubugye, USA.

Nimbkar, N. (2008). Issues in safflower production in India. In S. E. Knights \& T. D. Potter, (Eds.), Safflower: Unexploited potential and world adaptability. Proceedings of the $7^{\text {th }}$ International Safflower Conference, Wagga Wagga, New South Wales, Australia.

Nimbkar, N. (2002). Safflower rediscovered. Times Agricultural Journal, 2, 32-36.

Moatshe, O. G., \& Emongor, V. E. (2018). Genotype, plant density and seasonal effects on phenological stages of safflower (Carthumus tinctorious L.) in Sebele, Botswana. International Journal of Science and Research, 1201-1210. https://doi.org/10.21275/ART20203114

Oduro, I., Ellis, W. O., \& Owusu, D. (2008). Nutritional potential of two leafy vegetables: Moringa oleifera and Ipomea batatas leaves. Scientific Research and Essay, 3(2), 057-060. Retrieved from https://www.academic journals.org/SRE

Ogungbenle, H. N., \& Omosola, S. M. (2015). The comparative assessment of nutritive values of dry Nigerian Okra (Albelmoschus esculentus) fruit and oil. International Journal of Food Science and Nutritional Engineering, 5(1), 8-14. https://doi.org/10.5923/j.food.201505501.02

Okaka, J. C., \& Okaka, A. N. O. (2001). Food composition, spoilage and shelf life extension (pp. 54-56). Ocjarco Academic Publishers, Enugu, Nigeria.

Pearson, D. (1976). Chemical Analysis of Foods (7th ed., pp. 72-496). Churchill Livingstone, London, UK.

Rouphael, Y., Cardarelli, M., Bassal, A., Leonardi, C., Giuffrida, F., \& Colla, G. (2012). Vegetable quality as affected by genetic, agronomic and environmental factors. Journal of Food Agriculture and Environment, 10(3\&4), 680-688. Retrieved from https://www.researchgate.net/publications/235799237

Sigh, V., Jadhav, R. R., Atre, G. E., Kale, R. V., Karande, P. T., Kanbargi, K. D., ... Rajvanshi, A. K. (2017). Safflower (Carthumus tinctorious L.) —An underutilised leafy vegetable. Current Science, 113(5), 857-858. Retrieved from https://www.researchgate.net/publication/320098853

Sodamade, A., Bolaji, O. S., \& Adeboye, O. O. (2013). Proximate analysis, mineral contents and functional properties of Moringa oleifera leaf protein concentrate. Journal of Applied Chemistry, 4(6), 47-51. https://doi.org/10.6084/M9.FIGSHARE.1097420

Turan, M., Kordis, S., Zeuin, H., Dursan, A., \& Sezen, Y. (2003). Macro and micro mineral content of some wild edible leaves consumed in eastern Anatolia (pp. 129-130). Taylors and Francis. https://doi.org/ $10.1080 / 090647103100095$

Weiss, E. A. (2000). Oilseed Crops (2nd ed., Chapter 4, pp. 93-129). Blackwell Science, Oxford.

\section{Copyrights}

Copyright for this article is retained by the author(s), with first publication rights granted to the journal.

This is an open-access article distributed under the terms and conditions of the Creative Commons Attribution license (http://creativecommons.org/licenses/by/4.0/). 